2003

\title{
Mexican Suite: A History of Photography in Mexico
}

Susana Martínez

Follow this and additional works at: https://via.library.depaul.edu/dialogo

Part of the Latin American Languages and Societies Commons

\section{Recommended Citation}

Martínez, Susana (2003) "Mexican Suite: A History of Photography in Mexico," Diálogo: Vol. 7: No. 1, Article 20.

Available at: https://via.library.depaul.edu/dialogo/vol7/iss1/20

This Article is brought to you for free and open access by the Center for Latino Research at Digital Commons@DePaul. It has been accepted for inclusion in Diálogo by an authorized editor of Digital Commons@DePaul. For more information, please contact digitalservices@depaul.edu. 


\section{MEXICAN \\ A HISTORY OF \\ PHOTOGRAPHY \\ IN \\ MEXICO \\ Review by Susana Martínez}


Originally published in 1994 as Fuga Mexicana, un recorido por la fotografía en México, this visually enticing book is finally available to English language readers as Mexican Suite: A History of Photography in Mexico (2001). This edition has been revised to include explanatory notes for a reader that might be less familiar with Mexican history, making it an accessible resource for the general public, students, and scholars. Progressing chronologically, Mexican Suite provides an excellent visual and textual overview of the development of photography in Mexico from the 1840s to the present. Divided into eleven chapters: Overture, Ritornello, Canon, Pastorale, Oratorio, Requiem, Capricho, Toccata, Counterpoint, Danzón, and Fantasía, the visual arrangement of the black and white photographs works in perfect harmony with the musical compositions; stirring a wide range of emotions in the reader. These exquisite images challenge the reader to consider not only the stories they tell, but more importantly, the manner in which Mexico has been captured on film over the last two centuries.

Tracing the earliest visual reproduction even centuries before the arrival of the first camera to Mexico - the image of the Virgin Mary on Saint Juan Diego's cloak, Olivier Debroise notes that the second edition of Father Luis Becerra Tanco's Felicidad de Mexico en el principio, y milagroso origen que tubo el santuario de la Virgen Maria de Guadalupe (first published by Viuda Calderón in 1675) included an anonymous engraving explaining, in scientific terms, how the image of the Virgin came to appear on Juan Diego's cloth after her fourth apparition on the Hill of Tepeyac. From this early moment, we see two competing views of this medium - the use of photography either as documentary proof or as responding to an artistic and subjective aesthetic.

A more common beginning is to trace the origins of photography to the camera obscura (first constructed in 1545 by the Dutchman Reiner Gemma Frisius and widely used after the publication of a treatise by the Neapolitan scientist Giovanni Battista Della Porta), and its variant, the camera lucida. In fact, Debroise explains that the "invention of photography was less a question of finding a way to reproduce images than of retaining them, fixing them permanently on a support" (18).

The daguerreotype (named after Jacques Louis Mandé Daguerre) became very fashionable among the European middle class during the first half of the nineteenth century. The author explains that the daguerreotype "consists of a small sheet of copper bathed in a thin coating of polished silver that reflects the sitter's face like a mirror and secures a permanent image of incredible clarity and detail. Depending upon the angle at which it is viewed, the image appears negative or positive. The silver is perfectly smooth, so highly polished that it is without any apparent grain. Today, more than one hundred and fifty years later, the daguerreotype image remains unrivaled for clarity and permanence" (19).

Mexico embraced this technological innovation with wholehearted enthusiasm, creating a virtual "daguerreotype mania." On December 3, 1839, the French engraver Louis Prélier arrived in Veracruz with two cameras purchased in Paris. He organized a public demonstration (as Daguerre had done only months before) and transmitted the wonders of this port city to plates. Weeks later, Prélier repeated the demonstration in the plaza in Mexico City, reproducing the image of the cathedral. Barely two years after the first cameras arrived, "professional" photographers appeared in Mexico - "Fugitive from the traditional visual arts, these adventurers came in search of easy money" (20).

Itinerant photographers traveled to remote towns with a camera and accessories that weighed at least 70 kilos and were very fragile and difficult to transport. From this moment, the insertion of photography into Mexican culture was widespread and profound. One journalist wrote that in less than two decades after the introduction of photography into Mexico, "it had become so common that families have their photographer in the same way that they have their lawyer or doctor" (20). The price, however, was exorbitant; during the 1840 s daguerreotypes ranged from 2 to 16 pesos. Madame Calderón de la Barca informed her mother in a letter written from Mexico in 1840 that "a French cook receives some 30 pesos [per month], a housekeeper 12 to 15 , a butler around 20 or more, a footman 6 or 7 , servants and chambermaids 5 or 6 , a gardener 12 or 15" (22). The clientele, therefore, was mostly made up of wealthy land-owning families, rich traders along the road from Veracruz to Mexico City, and miners from the center and north of the Republic that typically squandered their hard earned wages as quickly as they made them.

The itinerant daguerreotypists are but one example of how photography served class interests from the beginning. Representing the other side of the social spectrum, this technology was also employed, as of 1855 , to identify criminals. During the French Intervention in Mexico, photography was used to control prostitution. In 1865, Maximilian ordered the compilation of an archive to house the police and clinical records of Mexico City's prostitutes, including their portraits. Images of prisoners' sexual organs and physical deformities (implicated as the origins of their real or alleged criminal behavior) circulated in Mexico City to satisfy the public's morbid curiosity. In fact, when Jesús Arriaga, the legendary "Chucho el Roto," escaped from prison in 1882,300 copies of his portrait were printed for sale. But the value of these early mug shots was often undermined since the accused inflated their cheeks or found other ways to deform their appearance.

On the other side of the country, the daguerreotype served another function altogether: to reproduce ancient monuments on the verge of vanishing. Uxmal, Kabah, and Labná - Maya architecture of the Puuc region - were photographed by the English draftsman Frederick Catherwood. Baron Emmanuel von Friedristhal, head of the Austrian diplomatic corps in Mexico and an amateur archaeologist, traveled with the U.S. diplomat John Lloyd Stephens to the Yucatán in 1841. Describing their importance, Debroise writes, "Despite their 'scientific' intentions, these early explorers photographed like 'artists,' less interested in precise description than in awe-inspiring effect. In this sense, their work is ambiguous. For while they initiated the practice of archaeological photography, in the final analysis their impact was greater as creators of a particular vision of Mexico" (88). This point is well taken, particularly because the wide-range of photographs in Mexican Suite stimulates us to consider the manner in which imaginings of Mexico have been created and transmitted over the years.

The chapter titled Pastorale, for example, contains images of volcanoes, pyramids, folkloric dancing such as the jarabe 
tapatio, and human types such as the tehuana and china poblana. These "typical" images of Mexico are complemented by an impression commonly held by foreigners searching of something more "authentic." In an article published in Helios (March 31, 1935) Eugene Witmore states, "Mexico is literally a photographer's paradise. Each tree, cactus, and flower, the thousands of Indians, campesinos, heavily loaded burros patient little animals -fields of maguey, the clouds, mountains, rocks, markets, gardens, parks, historical buildings, arches, monuments, all attract the photographer. These are different from anything in the United States, and little has been photographed by a million people before you, as in the case with most subjects north of the Rio Grande" (62). This idyllic notion of Mexico as a photogenic nation explains the fact that landscape photography reached its peak of popularity at the end of the nineteenth century. Interestingly, several photographers of the North American frontier, such as William Henry Jackson, crossed the Rio Grande to work in Mexico. Hugo Brehme's Erupción del Popocatépetl 1920, En la cima de la Iztaccíhuatl ca. 1920, and Cholula, Puebla, Pirámide ca. 1920-1925, clearly demonstrate that the history of landscape photography in Mexico can also be read as a nationalistic construct linked to the promotion of tourism.

In 1951, the Mexican photographer Luis Márquez insisted, "Mexico is an absolutely photogenic country [with] its archaeological ruins, colonial monuments, and unusual landscape. The development of photography as experienced [here] is based in this" (65). Ultimately, their importance as photographers - be they foreigners or Mexican - lies in being creators of a particular vision of Mexico.

Although Debroise states that in the history of Mexican photography, nudity is extremely rare, Paul-Emile Miot's barebreasted woman - Indian Woman, Veracruz ca.1869-1870 - is an example of a pseudo-ethnological portrait closely related to a concept of primitivism and tropical exoticism that was common throughout the nineteenth century. This genre mixes eroticism and exoticism of semi-nude indigenous women with the idealization of popular types, such as Hugo Brehme's China poblana, ca. 1920, Mérrille's Cargador, ca. 1876, Cruces y Campa's Remeros, ca. 1876, and C.B. Waite's Tlachiquero Drawing Pulque from the Maguey, ca. 1900 to represent Mexican society on the brink of urbanization. While Debroise calls attention to foreigner's fascination with Mexico's "informal sector," he also reminds the reader of the issue of self-identity: "In contrast to the way that 'First World' countries defined themselves, Mexico - a nation always at the edge of civilization - developed a strange sense of 'internal exoticism' and adopted the codes established by foreign travelers for its own national self-definition" (115). These costumbrista scenes that defined people by their function or trade serve a documentary purpose that can be described as anthropological photography. The fascination with the tehuana's elaborate costume, made famous by Frida Kahlo, is a case in point. In 1873, Lorenzo Becerril visited Tehuantepec and began photographing women's festive dresses. Debroise explains that the attire of the women of Tehuantepec is unique: "Spanish (or Gypsy) in concept, it possesses both Asian and Precolombian elements and, simultaneously, something of the European Baroque" (147). Twentieth century photographers such as
Edward Weston and Tina Modotti, Manuel Alvarez Bravo and Lola Alvarez Bravo, Sergei Eisentein and Edouard Tissé, Flor Garduño, Rafael Doniz, Pablo Ortiz Monasterio, and Graciela Iturbide, among many others, continued to focus their cameras on the tehuana going about her daily activities. Among their favorite images of this figure of Mexican mythology were tehuanas washing clothes in the river, feeding animals, and, of course, grinding corn. Diego Rivera visited Tehuantepec in 1922 , on the advice of José Vasconcelos, and this experience inspired his murals in the Ministry of Public Education. Debroise clarifies that Frida Kahlo's self-creation as tehuana is merely the culmination of a long process.

In the chapter titled Danzón, the author discusses the work of Mexican photographers Manuel Alvarez Bravo and Lola Alvarez Bravo, Tina Modotti, and the North American Edward Weston. An early example of Manuel Alvarez Bravo's photographic tricks is his shot of the Popocatépetl covered with snow. In reality, it is a pile of sand with some twigs in the foreground, and Debroise wonders whether it was meant to poke fun at Hugo Brehme's captivating volcanic landscapes. Here we can see Debroise's uneasiness with photomontage. Perhaps his uneasiness lies in the fact that these images deceive the public, since he sustains that photography lays claim to a special, direct relationship with "reality" (243). A sense of nostalgia permeates this latter part of the collection, recalling an era when the camera "froze" a certain moment in time.

In Fantasia, the final chapter, the author provides examples of this manipulative practice. Now, the "picturesque" images of rural Mexico give way to disquieting shots of Mexico City. Tina Modotti's socially minded photographs of workers in the slums and streets of Mexico City reveal images of poverty rarely seen before. Modotti's Elegance and Poverty, ca. 1928 and Lola Alvarez Bravo's El sueño de los pobres II, 1935 are eloquent images of class struggle. They aimed their cameras at people going about their everyday lives. With respect to EI sueño de los pobres, Lola Alvarez Bravo explained, "Sometimes I wanted to say something, and photography wouldn't let me. So I would take a piece of cardboard, make a sketch, choose some negatives, print them to necessary size, cut and glue them (to the paper)" (238). The final product is a cruel image of a machine, churning out mint coins in stark contrast to a poor child, dressed in rags, sleeping on rough boards. The powerful juxtaposition of elements speaks volumes, leading the author to admit, "She did not attempt to modify reality, but to complement it by presenting an ideal dimension that the camera alone could not provide" (240).

This ambitious collection presents a way of seeing Mexico, past and present. Every time the reader turns the page, he or she witnesses how a range of artists observed the country and its people over time. This illustrated history of Mexico is an excellent overview that will serve as an essential guide and a vital teaching tool to artists, collectors, and art historians.

Susana Martinez is Assistant Professor in the Department of Modern Languages at DePaul University.

\section{Didilogo 82}


